\title{
Misbehaviour of Students in Palu City
}

\author{
(Reflection of Character Building)
}

\author{
Hasdin \\ Universitas Tadulako \\ Palu, Indonesia \\ hasdinbangkep@gmail.com
}

\begin{abstract}
The objective of the research is to find out the forms and the causes of the misbehavior of the students in Palu City. This is qualitative descriptive research. The research was conducted at 10 schools in Palu City, which consisted of 5 (five) Junior High schools and 5 Senior High School located at five subdistricts at Palu City Subjects of the research were 10 guiding and counseling teachers. Data of the research were collected through interview and documentation. The data were analyzed through three phases:, reduction, displaying and drawing the conclusion. Result of the research indicates that: 1) forms of the misbehaviour of the students are: frequently absent from school, being late to class, truancy, smoking in school, stole, students brawl, defamatory friends, sexual harassment, carelessly dressed, bullying, drug abuse, drinking, watching porn videos, drug dealers, sexual intercourse in schools, against the teacher (spitting when the teacher was teaching), spray water to teachers when teaching, throwing litter bin to the teacher and carrying weapons to school. 2) causes of misbehaviour of the students in Palu City are: laziness, influenced by friends, do not like the teacher, envious to the other students, quarrels and taunt to other students, from poor family, broken home, experimenting, lack of parental supervision, promiscuity, internet media, lack of awareness of students, and students' misconceptions. Based on the data analysis, it could be concluded that there are two kinds of students' misbehavior are ordinary misbehavior and juvenile delinquency (involved in crimes). The causes of the misbehavior of the students in Palu City are internal and external factors.
\end{abstract}

Keywords—misbehavior of the students; character building.

\section{INTRODUCTION}

A hundred years ago or a few years ago, the world seemed very beautiful and feels full of peace, in which people in past times are submissive and obey the rules set in the environment where they live. They have a fear of sin against the CreatorThey have a fear of sin on the creator which must be accounted for after we die, so they are very afraid to acts that may lead to sin or a problem either on themselves or on others. But how powerful the advances that developer may not realize. In this case that is very visible in the development of the times is juvenile delinquency. One visible manifestation of juvenile delinquency, for example, promiscuity, free sex, robbery, theft, deviations and behaviors prohibited by religion or law.

Juvenile delinquency in Indonesia, especially teenagers or young people doing a lot of very inappropriate actions can be seen very clearly and immediately apparent that in this era of globalization, It could be influenced from foreign countries and also within our country is related to behavior, properties or motifs of clothing and so forth. So in this case, I will review the types and causes of the delinquency.

Delinquency in the city of Palu in the last few years is quite alarming the society. There are many kinds of mischief and contributing factors are also varied. Type delinquency in Palu, such as theft, assault, narcotic crime, traffic accident, rape, escape immature female, destruction, promiscuity, drug abuse loud, lewd acts and abortion [1]

Today, the world of education face very complex problems that need attention. Such problems include a curriculum change so that schools are less ready to implement, teachers who are less qualified in terms of their education level, school facilities that are not fully equipped, and issues on students that caused the decline of social manners and moral ethics in the practice of school life which resulted in a number of negative behaviours that are very disturbing the society. Such behaviors include the proliferation of various aberrations norms of religious and social life embodied in the form of student misbehavior in school

Similar problems from year to year occur in schools, both the level of secondary school (SMP) to High School (SMA) in the city of Palu. Problems regarding violations committed high school students in Palu also occurred in schools in general and quite diverse, ranging from smoking, ditching, fighting, brawling, drinking, stealing, and the most serious is the case of narcotics and sexual harassment.

The emergence of problems should be followed by controlling effort conducted by schools, including in the form of sanctions. The sanctions provided in accordance with the type of offenses committed by the students themselves. However, this effort needs to be retightened considering there are many opportunities for students to commit offenses. This does not only take the role of the teacher but also takes the role of parents, friendship and daily milieu are also effective in educating the children. So, we recommend reducing violations of various elements that are needed to establish a better and good quality of state generation,

\section{METHODS}

\section{A. Type of Research}

This is a qualitative descriptive research. This research investigated and described the type of students' delinquency and the factors caused misbehavior of the students' in the city of Palu. 


\section{B. Time and Place of Research}

This research was conducted in May 2016 in SMP 6 Palu, SMPN 15 Palu, SMP Negeri 7 Palu, SMPN 18 Palu, SMP Negeri 3 Palu and SMA Negeri 3 Palu, SMK Negeri 3 Palu, SMKS PGRI, SMK 6 Palu, and SMA Katolik Palu.

\section{Subjects of Research.}

The subjects of this research were ten (10) teacher of Counselling (BK) or School Principal (for schools that do not have a teacher of Counselling).

\section{Technique of data collection}

Data collection techniques used in this study are as follows:

\section{1) Interview Techniques (Interview)}

The interview is a question and answers verbally between two or more people directly. Interviewer (interviewer) who asked questions and the interviewee provides answers to the questions (Usman and Akbar, 2003: 57) [2]. This technique is carried to obtain data relating to the type of student delinquency and the factors cause students' misbehaviors.

\section{2) Documentation Technique}

Documentation technique is a technique of collecting the data through documentation (Usman and Akbar, 2003: 73). This technique is used to obtain data related to the type of students' misbehaviors.

\section{E. Technique of Data Analysis}

According to Moleong (2002: 190) [3], the data analysis process starts with examining all available data from different sources, from interviews and documentation, data reduction, the next step is to construct the data collected and then categorize the data. The categories are done while making coding. The last stage of the data analysis is examining the validity of the data.

\section{RESULTS AND DISCUSSION}

Types of student delinquency and factors that lead to students' misbehaviors in Palu as follows:

Types of Students' delinquency of SMP Negeri 6 Palu, namely: frequently absent from school, being late to class, truancy, using mobile phones while studying, smoking, stealing, fighting between students, defamatory friends, and sexual harassment. The factors that cause students' delinquency at SMP Negeri 6 Palu, are: influence of adverse circumstances, the lack of motivation to learn, economic background, did not like the teacher who taught him, the influence of friends, envious to other friends, (Source: teacher of counseling atSMPN 6 Palu).

Types of student misbehavior at SMA Negeri 3 Palu, sneaky away from the class. A factor contributing to the delinquency in SMAN 3 Palu, are: students were not interested in learning and lazy to learn. (Source: teacher of counseling at SMA Negeri 3 Palu)

Type of students' delinquency at SMPN 15 Palu, were: being late for school, carelessly dressed, absent from school, truancy, bullying, fighting, drug abuse, alcoholic beverage, smoking, watching porn videos, medicine abuse (Komix cough medicine)and airports illegal drugs. The factors that led to the delinquency of students in SMPN 15 Palu, were: economic factors, broken home, experimenting, hanging out with bad friends (Source: teacher of counseling at SMPN 15 Palu).

The types of student misbehavior at SMK Negeri 3 Palu, namely: coming late to school, carelessly dressed, absent from school, truancy, fighting, drug abuse, drinking, smoking, watching porn videos, medicine abuse (Komix cough medicine), sniffing glue fox, sexual intercourse, using mobile phones while learning. A factor contributing to the delinquency of students in SMK Negeri 3 Palu, namely: lack of parental supervision, broken home, experimenting promiscuity, and economic issues (Source: teacher of counseling at SMK Negeri 3 Palu).

Types of students' misbehavior in SMP Negeri 7 Palu, namely: smoking (disposable electric cigarette), hooky to hang out at cafe, a fight between friends and between classes, negligent, sexual harassment (peep panties women), against the teacher (spitting when the teacher was teaching) and sprayed water to the teacher while teaching. Factor contributing to the delinquency of students in Junior High School 7 Palu, namely: broken home, family environment less attention to the development of children, environmental influences society, peer influence, and the influence of Internet media (Source: teacher of counseling at SMP Negeri 7 Palu).

Types of students' delinquency at SMKS PGRI Palu, were: drugs abuse, smoking, immoral deeds, throwing litter bin to the teacher, truancy, being late to school, and absent from school. Factors cause the students' delinquency at SMKS PGRI Palu, were: broken home, lack of parental control and attention, in the conducive social environment, peer influence, lack of students' motivation in learning. (Source: teacher of counseling at SMKS Negeri Palu).

Types of students' delinquency at SMP Negeri 18 Palu, were: truancy, being late to school, fight with other friends, smoking in the school area, and absent from school. Factors that lead to the delinquency of students at SMP Negeri 18 Palu, were: family factor, environmental factor, and does not like to the teachers (Source: teacher of counseling at SMP Negeri 18 Palu).

Types of student misbehavior in SMP Negeri 6 Palu, namely smoking, truancy by climbing the fence of the school, drugs abuse, fights between students, and carrying weapons. Factors that lead to the delinquency of students in SMK Negeri 6 Palu, peer and family factors (Source: teacher of counseling at SMK Negeri 6 Palu).

Types of student misbehavior in SMP Negeri 3 Palu, namely: truancy, smoking in the school environment, fighting among students, steal. The factors that cause delinquency student SMP Negeri 3 Palu, namely: students bored in school, experimenting, influenced by friends, envious to other friends, miscommunication with other students (Source: teacher of counseling at SMP Negeri 3 Palu).

Types of student misbehavior at SMA Katolik Palu, were: being late to school, drugs abuse. The factors cause students' 
delinquency at SMA Katolik Palu were: being late to school because of oversleeping in the morning, experimenting in drugs, lack of parental and teacher control(Source: teacher of counseling SMA Katolik Palu).

The terms of students in this paper refer to juvenile, as the stage of age requires attention, especially in the field of education. The classification of the age of students as juvenile used by the researcher refers to a theory proposed by Ref. [4], the age of juvenile are age between $13-20$ years old. In Indonesia, this group of age is the age of students of Junior High and Senior High School. There are many students who failed to pass this phase of adolescence. It is the period when someone is doing something was influenced by many factors such as environment, milieu who daily has interaction with the students. This group of age is fully independent and autonomous to take a stand. Therefore, when students commit delinquency (juvenile delinquency), there is a possibility that they did not act alone, or at least the delinquency was not their initiative.

Ref. [5] emphasized that "juvenile delinquency etymologically is interpreted as crimes committed by children". In line with these opinions, Hasan explained that the delinquency/juvenile delinquency is "anti-social acts committed by teenagers anti-social acts committed by teenagers which if committed by an adult will be categorized as a crime "Simanjuntak noted that an act is called delinquency if such actions contradict the norms that exist in the society where he lives or an anti-social acts in which it contains the elements of an anti-normative. Meanwhile, according to Article 1 (2) of Act on Juvenile Justice, Juvenile is: children who commit criminal acts or children who break outlawed for children, either by legislation or by other legal regulations applicable in the community. [1]

A wide variety of student misbehavior in Palu indicates that control the schools, in this case, the teacher was not yet optimal. Although on the other hand, it was undeniable that students' misbehavior also due to the poor condition of students' psychiatric or mental state. When we examined the kinds of misbehavior of students in the city of Palu, they were not just an ordinary delinquency, but they were incredible mischiefs, which can be categorized as crimes, such as drug abuse and drug trafficking. These types of delinquency were typically done by an adult.

The role of the school in terms of controlling students during school hours is very important. Factors that lead to student misbehavior in Palu is, in fact, most of the actual cause could be anticipated by the school if the school perform with maximum control. It is undeniable that the school has its limitations eliminate the occurrence of such student misbehavior. Efforts to educate, nurture and train the child to grow into good children is not enough simply done by one party, but it takes a synergy of many parties, such as parents and the community. [6]

Control theory is often called social control theories derived from the assumption or presumption that individual in the society has the same tendency of likely to be good or bad (Hagan, 1987: 164) [7]. Control perspective is a perspective that is limited to the explanation of delinquency and crime.
This theory laid the causes of crime on individual bonds or his/her weakness on social bonds with his/her community, or the breakdown of social integration. The groups that are weak on social bonds tend to break the law because they feel a bit bound by the conventional rules. If a person feels close to the conventional group, he has a little tendency to deviate from the rules of the group. But if there is social distance as a result of the severing of bonds, people will feel freer to deviate (Hirschi, 1969: 16). [8]

According to Hagan that the good or bad of someone depends entirely on the community. He would be good if people make such a way and become worse when people make it so. Therefore, it is not surprising that those who adopt this concept argue that social bound of a person with his community is seen as a deterrent for misbehavior. Someone will $\mathrm{e}$ weaken or interrupted his social bond with the community when in the society had occurred degeneration function of social control agencies of both formal and informal. Informal social control agent includes the means of social control for nonpositive law in the context of our society these facilities may be identified with indigenous institutions, a system of social control that is not written yet gained recognition of enforceability in society.[5]. This means that when in a society, where the environmental conditions do not support the well-functioning of social control institution, more or less will result in weakening or breakdown of social bond with their communities' members; and in turn will give them the freedom to behave deviate.

Referring to the type, student misbehavior in Palu, there can still be handled by the school, but there also must be addressed by the authorities, such as police and the National Narcotics Agency. For normal or mild delinquency, the school still can foster students to be able to turn out to be a good student. But for unusual or severe delinquency, the school should cooperate with the authorities to handle the case.

It must be realized that the student is not solely a mandate from parents, but also the mandate of the state to the school or teachers to educate them to be children who are expecting to build the nation in the future. Thus, the school should carry out these responsibilities in full seriousness. Many students who commit acts of delinquency in the city of Palu, however, this issue must not allow us to judge the student as the sole source of error, but in this case, the students should be seen as victims of the negligence of adults, the teachers, parents, and the community. In other words, adults (teachers, parents, and community) contributed to many acts of delinquency committed by students in Palu.

Student misbehavior in Palu as found in the results of this study should be addressed wisely by taking countermeasures. Schools must work together with other components, such as parents (families) and the community through school committees. One solution to counteract the negative behavior of students is to conduct training and education of religious values in school, home, and community. In addition, the control of teachers, parents and the public on the activities students must also continue to be optimally done. 


\section{CONCLUSION}

Forms of the misbehaviour of the students are: frequently absent from school, being late to class, truancy, smoking in school, stole, students brawl, defamatory friends, sexual harassment, carelessly dressed, bullying, drug abuse, drinking, watching porn videos, drug dealers, sexual intercourse in schools, against the teacher (spitting when the teacher was teaching), spray water to teachers when teaching, throwing litter bin to the teacher, and carrying weapons to school. 2) causes of misbehaviour of the students in Palu City are: laziness, influenced by friends, do not like the teacher, envious to the other students, quarrels and taunt to other students, from poor family, broken home, experimenting, lack of parental supervision, promiscuity, internet media, lack of awareness of students, and students' misconceptions.

Schools should set synergy with other educational components, such as parents and communities to nurture and educate students with religious values and control over the activities of students. Schools also should evaluate the learning atmosphere in schools and teach quality of the teachers.

\section{REFERENCES}

[1] Hasdin,Pendidikan Budaya dan Karakter Bangsa di sekolah sebagai Solusi Menanggulangi Kenakalan Anak di Kota Palu. Jurnal Kreatif, Vol. 15 No. 2, h.30-37,2012.

[2] Usman, Husaini dan Akbar, Purnomo Setiady,Metode Penelitian Sosial. Jakarta: Bumi Aksara, 2003.

[3] Moleong, Lexy. J. Metodologi Penelitian Kualitatif. Bandung: Rosdakarya, 2002.

[4] Daradjat, Zakia,Faktor-faktor yang Merupakan Masalah dalam Proses Pembinaan Generasi Muda. Bandung: Bina Cipta, 1985.

[5] Hadisuprapto, Paulus. Juvenile Delinquncy (Pemahaman dan Penanggulangannya). Bandung: Citra Aditya Bakti, 1997

[6] Hasdin, Kebijakan Kriminal Kepolisian terhadap Kenakalan Anak di Kota Palu. Jurnal Pendidikan Ilmu Sosial (JurPIS), Vol. 1, No. 15, h,120-133, 2013.

[7] Hagan, John. Modern Criminology, Crime, Criminal Behavior and Its Control. Songapore: McGraw Hill Book Com.,1987.

[8] Hirschi, Travis, Causes of Delinquency, Berkeley: University of California Press, 1969. 